\title{
Our experience of a left-sided approach to anterior cervical discectomy
}

\section{Anterior servikal diskektomide soldan yaklaşım tecrübelerimiz}

\author{
Hüseyin Bozkur $t^{1}$, Mustafa Karademir ${ }^{1}$
}

Sivas Cumhuriyet University School of Medicine, Department of Neurosurgery, Sivas/Turkey

Corresponding author: Mustafa Karademir, Sivas Cumhuriyet University School of Medicine, Department of Neurosurgery, Sivas/Turkey

E-mail:krdmr58@gmail.com

Received/Accepted: March 05, 2019 / March 20, 2019

Conflict of interest: There is not a conflict of interest.

SUMMARY
Objective: To emphasize the advantages of a left-sided approach compared to opening the cervical region from the right side in patients with cervical disc hernia undergoing surgery for any reason.

Method: A total of 10 patients with a history of surgery in the right cervical region were operated on with a left-side approach because of disc hernia at a single cervical level between 2013 and 2018. The patients comprised 6 males and 4 females. Of the whole patient group, 5 had previously undergone surgery for cervical disc hernia, 3 for goitre, 1 with hydrocephalus because the shunt traversed the medial of the distal end of the sternocleidomastoid muscle, and 1 patient who had not been operated on but had goitre of giant dimensions extending to the right.

Results: All the patients were diagnosed with cervical disc hernia from MRI findings and neurological examination. The operation of single level cervical disc surgery was performed with an approach from the left in all 10 patients avoiding opening from a recurrence area. No complications developed and the complaints were seen to recover.

Conclusions: In the light of previous reports in literature, it can be emphasized that to prevent complications in cervical disc surgery, rather than an approach from a previously operated region, it could be more advantageous to open from the opposite side.

Keywords: Anterior, cervical disc hernia, left-side approach

ÖZET

Amaç: Bu çalışmada sağ taraflı açılışla servikal bölgeden herhangi bir nedenle opere olmuş servikal disk hernili hastaların soldan yaklaşımın avantajları vurgulanmıştır.

Yöntem: 2013-2018 yılları arasında özgeçmişinde sağ servikal bölgeden opere olmuş 10 hastanın servikal tek seviye disk hernisi nedeniyle soldan yaklaşım ile operasyonu yapıldı. Hastaların 6 sı erkek 4 ü kadındı. Tüm hasta grubunun 5 tanesi servikal disk hernisi nedeniyle opere olmuştu, 3 hasta guatr nedeniyle opere, 1 hasta hidrosefali nedeniyle opere olmuş şant distal ucu sternokleidomastoid kası medialeinden geçiyordu, 1 hasta ise opere olmamış dev boyutta sağa uzanan guatrı mevcuttu.

Bulgular: Tüm hasta grubu MRI bulguları ve nörolojik muaynesi ile servikal disk hernisi tanısı aldı. Nüks bölge açılışından kaçınılarak 10 hastada tek seviye servikal disk cerrahisini soldan yaklaşımla opere edildi. Komplikasyon olmad1, şikayetlerin geçtiği görüldü.

Sonuç: Servikal disk cerrahisinde komplikasyonları önleme açısından reoperasyon bölgesinden yaklaşımdansa karşı taraftan açılışın daha avantajlı olacağını literatür eşliğinde vurgulamaktayız.

Anahtar sözcükler: Anterior servikal disk hernisi, soldan yaklaşım 


\section{INTRODUCTION}

Cervical disc hernia is a disease showing signs and symptoms with pressure of the intervertebral nucleus pulposus on the nerve root or spinal cord made by tearing the anulus fibrosis in an acute or chronic process. It can be differentiated as intraforaminal, paracentral or central disc hernaition according to the localisation ${ }^{1}$.

An anterior cervical approach is widely used in disc diseases of the cervical region, tumour, trauma and infections. It was first described in cervical diseases by Robinson and Smith in 1955, then anterior cervical approach techniques with or without fusion were later published by Cloward, Bailey and Bagley, Hirsch, Simmons and Bhalla, and Wilson and Campbell. With this approach, decompression is applied of the pressure on the cervical root and spinal cord related to the disc or osteophyte, and stabilisation can be provided ${ }^{2}$.

However, the results of this approach can show variability associated with some factors. In operations performed in the cervical region for various reasons, some conditions can make an approach from the right side more difficult in cervical disc surgery, such as thyroid diseases reaching giant dimensions, and cervical region localisation of the distal ends of a ventriculoperitoneal shunt previously applied to patients with hydrocephalus, and these cause an increase in the complication rate. The decision of the approach to be taken is based on multiple factors, including the surgeons training, the surgeons dominant hand, level of proposed surgery, and patient history of prior neck surgery. The risk of injury to the recurrent laryngeal nerve (RLN) is often cited as the basis for selecting the side of approach. Anatomic considerations are used as justification for the approach laterality decision. Unfortunately, there is no large clinical series correlating the risk of RLN injury with the side of approach, hence the debate ${ }^{3}$.

To prevent injury during the operation, the surgeon must know the course of the recurrent laryngeal nerve (RLN). On the right side, the RLN forms a belt around the right subclavian artery, and on the left, around the aorta. Injury to the RLN causes hoarseness, cough, aspiration, the feeling of a mass, dysphagia and vocal cord fatigue. If taken too far lateral when stripping the longus colli muscles, Horner syndrome may develop with the effect on the cervical sympathetic plexus. Too much distraction with a Caspar retractor causes postoperative neck pain. Although fusion with autograft is the gold standard method, pain which may develop in the graft site and donor site complications must not be ignored ${ }^{4}$.

The aim of surgical treatment is to remove the pressure on the spinal cord and nerve roots, preserve the alignment of the cervical spine, or restore it if it has been disrupted, to not cause any instability or impairment postoperatively, and to improve quality of life for the patient by eliminating the complaints and while doing this, to not cause any complications as far as possible 2 .

The aim of this study was to discuss in the light of the relevant literature the results of patients operated on in the anterior cervical region for any reason with an approach from the left to more easily reach the disc and to reduce the risk of complications in anterior cervical disc surgery.

\section{MATERIAL AND METHODS}

A retrospective review was made of 10 patients with complaints of neck and arm pain who were diagnosed with cervical disc hernia on cervical MRI and from neurological examination, and were operated on by a single surgeon (HB) between 2013 and 2018. The patients comprised 6 males and 4 females. All the patients were applied with anterior cervical discectomy and fusion surgery with a left-side cervical approach. All the patients had an incision scar in the anterior cervical region from previous surgery. Early and late term follow-up radiographs and cervical MRIs were taken. Postoperative patient satisfaction, operating time, complications were recorded.

Surgical technique: After determining the space from outside with fluoroscopy, the surgeon took a position on the left side and the assistant on the right side of the patient. The skin and subcutaneous tissue was entered with a transverse incision from the left cervical area and the platysma was opened parallel to the skin or vertically. After passing the superficial cervical fascia, between the sternocleidomastoid muscle and the omohyoid muscle, this was deepened with sharp and blunt dissection by retracting the vascular nerve bundle of the carotid and vagus to the left and the trachea and oesophagus to the right. The deep cervical fascia was stripped with blunt dissection. The cervical vertebra corpuses and the overlying longus colli muscles extending longitudinally to the right and left were visualised. The space was determined with fluoroscopy. The surgical area was imaged with a microscope. With the aid of bipolar coagulation, the longus colli muscles were stripped from the midline towards 
the lateral to be in the centre of the discectomy space. This stripping process requires care, especially at the C6-C7 level, otherwise there could be recurrence, and hoarseness could develop associated with thermal damage to the platysma nerve. After determination of the disc and body borders, a Caspar retractor was placed on the corpuses above and below. Distraction was applied to the space. Discectomy was performed until the posterior longitudinal ligament was seen. The integrity of the posterior longitudinal ligament was disrupted and widened as far as the foramens. The dura was seen below, and the uncinate joints and ossified bones were removed with a Kerrison Rongeur. The corpus surfaces were cleaned from the end-plates with a curette and drill, then decorticated. The space was measured, then for fusion, cages made from different materials (PEEK [polyetheretherketone], titanium, carbon, tantalum) were placed filled with synthetic grafts or combinations.

\section{RESULTS}

The 10 patients operated on between 2013 and 2018 comprised $6(60 \%)$ males with a mean age of 49.16 years and 4 (40\%) females with a mean age of 50.25 years. In literature, the age range varies from 44-47 years ${ }^{5}$. All the patients underwent surgery with a left-side approach because of a single level cervical disc hernia. In the histories of the male patients, 3 had undergone previous surgery for cervical disc hernia, 1 because the distal end of a ventriculoperitoneal shunt had passed in front of the sternocleidomastoid muscle as a result of malpositioning, and 2 had been operated on because of goitre. In the histories of the female patients, 2 had been operated on previously for cervical disc hernia, 1 because of goitre, and 1 had not been operated on previously but had goitre of giant dimensions extending to the right. The disc spaces operated on were C5-6 in 5 cases, C3-4 in 2 cases, and C6-7 in 3 cases. Postoperatively, all the patients were pain-free. A rigid neck brace was used for 1 month. At the end of 1 month, the neck brace was removed and a cervical radiograph was taken. No complications developed in any patient. The routine operating time was seen to have been extended by $30-45$ minutes.

\section{DISCUSSION}

In previously published clinical series and case reports, it has been reported that after ASD operations complications could develop such as recurrent laryngeal nerve palsy, laceration of the pharynx and/or oesophageal wall, Horner syndrome, vertebral artery laceration, carotid artery or jugular vein injury, pneumothorax, respiratory failure, spinal epidural hematoma, wound site hematoma or infection, spinal epidural abscess, spondilodiscitis, dural tear and cerebral spinal fluid (CSF) leakage, meningitis, spinal cord injury, myelopathy, spinal root injury and additional radicular findings, cervical angulation and instability deformities, and displacement of bone graft or instrumentation graft ${ }^{6}$.

Using anatomic data, various texts and publications have suggested that there is less risk to the RLN with a left-sided approach ${ }^{7}$. A convincing argument has also been published for a right-sided approach at the cervicothoracic junction, which considers the $1 \%$ incidence of non-recurrent laryngeal nerve on the right. However, there are no available studies that have reported the risk of RLN injury and laterality of approach based on clinical outcomes ${ }^{8}$.

The recurrent laryngeal nerves follow different courses on the right and left sides of the cervical spine. On the right side, the RLN leaves the main trunk of the vagus nerve and passes anterior to and under the sublclavian artery. It then ascends in the tracheoesophageal groove. It frequently bifurcates before entering the larynx. On the left side, the RLN again descends parallel to the carotid but then passes under and posterior to the aorta at the ligamentum arteriosum. The nerve then ascends in the tracheoesophageal groove, slightly more medial in location than on the right side, to lie under the lateral lobe of the thyroid gland. Non-recurrence of the left inferior laryngeal nerve is rare and is associated with a right-sided aortic arch ${ }^{9,10}$.

In a cadaver study by Haller et al, it was reported that in anterior cervical disc surgery with an approach from the right or left side, at a high level or low level, the RLN was at the same risk as the hipogosal nerve arteria troidea superior and the superior laryngeal artery with a right-side approach ${ }^{11}$.

In a study by Jae Kyun Jeon et al, the differences observed between right and left -sided cervical approaches were summarised as follows; small vessels in the anterior neck were present, respectively, in $50.5 \%$ (trajectory on the left side) and in $49.1 \%$ (trajectory on the right side) at disc level $\mathrm{C} 3-\mathrm{C} 4$, in $30.3 \%$ and $28.8 \%$ at $\mathrm{C} 4-\mathrm{C} 5$, in $24.1 \%$ and $7.6 \%$ at $\mathrm{C} 5-\mathrm{C} 6$, and in $55.2 \%$ and $43.1 \%$ at C6-C7. There were no differences in the number of small vessels between the left and right sides at the upper cervical level (C3-C4-C5), but small vessels were less frequently observed on the right side at lower cervical levels (C5-C6-C7). 
Differences in oesophageal deviation were also observed, with less deviation to the right side $(0.63 \pm 0.35 \mathrm{~cm})$ than the left $(1.18 \pm 0.52 \mathrm{~cm})$. An oesophageal diverticulum was also observed in 1 case on the left side ${ }^{12}$.

In a cadaver study by Salman AbbasiFard et al, anterior cervical disc surgery with 6 different approaches showed that while there was no difference between the left and right side approaches in respect of complications, there was a difference between high level and low level anterior cervical approaches and it was reported that more care was required in the high level approach ${ }^{13}$.

Beutler et al reported that there was a higher risk of RLN injury in the re-operation area but there was no difference between right and left-sided approaches in respect of RLN injury risk ${ }^{14}$.

To the best of our knowledge, there is no largescale study in literature that has reported a difference in neurological complications between left and right-side approaches in anterior cervical disc surgery. Apfelbaum et al emphasised that the most important factor in preventing RLN injury was careful placement of the Caspar retractor and that the retractor should be loosened often and tension not maintained for a long time ${ }^{15}$.

There has been debate in literature about the complication of RLN injury related to malpositioning of autografts and synthetic grafts used for fusion in anterior approach surgery for cervical disc hernia. The current study is the first in literature to have discussed recurrence opening and the non-routine approach from the left side.

A factor that renders the approach from the left side difficult in anterior cervical discectomy is if the surgeon is right hand dominant and when it is considered that this increases the operating time and the risk of complications, it can be considered to be more difficult than the approach from the reoperation area. The most important stage in the approach from the left during surgery is that righthanded surgeons must be very careful when opening the PLL with a fine Kerrison and at the stage of advancing towards the left foramen.

\section{CONCLUSION}

In this study, it has been emphasised that an approach from the left side is more advantageous in the opening of a re-operation site in patients undergoing anterior cervical discecctomy. However, there is a need for further studies with many more patients to confirm these results as statistically significant.

\section{REFERENCES}

1. Yaycıoğlu S, Gökpınar D. Anterior girişimle ameliyat edilen servikal disk hernilerinin değerlendirilmesi (servikal disk ameliyat1).Adnan Menderes Üniversitesi T1p Fakültesi Dergisi. 2003, 4(2),11-14.

2. Orakdöğen $M$, Döşoğlu $M$, Ateş Ö, Demirbaş MA, Özdoğan C, Tevrüz M. The results of anterior approach in cervical disc hemiation. Acta Orthop Traumatol Turc. 1997; 3: 327-330.

3. Ebraheim NA, Lu J, Skie M, Heck BE, Yeasting RA. Vulnerability of the recurrent laryngeal nerve in the anterior approach to the lower cervical spine. Spine 1997; 22: 2664-7.

4. Netterville JL, Koriwchak MJ, Courey MS, Winkle M, Ossoff RH. Vocal fold paralysis following the anterior approach to the cervical spine. Ann Otol Rhinol Laryngol. 1996; 105: 85-91.

5. Kasimcan Ö, Kaptan H, Çakiroğlu K, Kiliç C. Servikal Disk Hernisinde Peek Cage'in

Erken Dönem Sonuçları. Archives of Neuropsychiatry/Noropsikiatri Arsivi. 2009, 46(3).

6. Özay R, Çetinalp NE, Kalan M, Oğur T. Dislocation and Spontan Resorbtion of the Bone Graft after Anterior Cervical Discectomy Operation: Case Report. Türk Nöroşirürji Dergisi. 2012, Cilt: 22, Sayı: 3, 232-234.

7. O'Shea J, Sundaresan N, Steinberger AA, Moore F. Surgical approaches to the cervicothoracic junction. In: Menezes AH, Sonntag VKH, eds. Principles of Spinal Surgery. New York: McGraw-Hill. 1996, 1253-61.

8. Geiger M, Roth PA, Wu JK. The anterior cervical approach to the cervicothoracic junction. Neurosurgery. 1995, 37: 704-9.

9. Nemiroff PM, Katz AD. Extralaryngeal divisions of the recurrent laryngeal nerve: surgical and clinical significance. 1982, Am J Surg ; 144: 466-9.

10. Skandalakis JE, Droulias C, Harlaftis N, Tzinas S, Gray SW, Akin JT. The recurrent laryngeal nerve. Am Surg. 1976, 42: 629-34.

11. Haller J M, Iwanik M, Shen F. H. Clinically relevant anatomy of recurrent laryngeal nerve. Spine.2012, 37(2), 97-100.

12. Jeon, JK, Oh CH, Chung D, Lee J, Choi SH, Choi E, Ji GY. Prevertebral vascular and esophageal consideration during percutaneous cervical disc procedures. Spine. 2014, 39(4), 275-279. 
13. Fard SA, Patel AS, Avila MJ, Sattarov KV, Walter CM, Skoch J, Baaj AA. Anatomic considerations of the anterior upper cervical spine during decompression and instrumentation: a cadaveric based study. Journal of Clinical Neuroscience. 2015, 22(11), 1810-1815.

14. Beutler WJ, Sweeney CA, Connolly PJ. Recurrent laryngeal nerve injury with anterior cervical spine surgery: risk with laterality of surgical approach. Spine. 2001, 26(12), 13371342.

15. Apfelbaum RI, Kriskovich MD, Haller JR. On the incidence, cause, and prevention of recurrent laryngeal nerve palsies during anterior cervical spine surgery. Spine. 2000, 25 (22), 2906-2912. 